\title{
Review of Business Growth Models: Methodology and the Assumption of Determinism
}

\author{
Matti Muhos* \\ matti.muhos@oulu.fi \\ Oulu Southern institute \\ University of Oulu, Finland, P.O. Box 4610, \\ FI-90014 University of Oulu, Finland \\ e-mail: matti.muhos@oulu.fi \\ *Corresponding author
}

\begin{abstract}
:
Numerous configuration models have attempted to clarify management priorities during the early stages of business growth. Earlier reviews have focused on the basic, visible characteristics of these models. Less attention has been paid to research methodology and basic assumptions. This study aims to fill this gap by review of configuration studies conducted over the past six decades. The focused meta-analysis reveals what kinds of research strategies, choices and time horizons, and empirical evidence are utilised for development of the models and what alternative views the models provide in relation to the assumption of deterministic firm growth. The study opens fresh perspectives to methodology and assumptions of the configuration studies and provides guidelines for future research.

Keywords: business growth models; review; growth stages; growth configurations; growth process; methodology; assumptions; small- and medium-sized enterprises; SMEs; enterprise development

Biographical notes: Dr. Matti Muhos is a Research Director at the Oulu Southern Institute at the University of Oulu. He holds a Doctorate in Industrial Engineering and Management. He participates in the editorial processes of several international journals as an associate editor, quest editor and advisory board member. His primary research interests are growth and the internationalisation of technology intensive SMEs including configurations and management viewpoints, the development of micro-companies and SMEs, technology intensive companies, agility, internationalisation processes and technology management.
\end{abstract}

\section{Introduction}

Firm growth and development have been studied extensively in the last decades. Many perspectives have been introduced to this arena including the static equilibrium theories (see e.g., Coase, 1937), stochastic models (see e.g., Gibrat, 1931), transaction cost theories (see e.g., Williamson, 1975), economics of growth theories (see e.g., Penrose, 1959), resource-based theories (see e.g., Penrose, 1959), evolutionary theories (see e.g., Nelson and Winter, 1982), organisational ecology theories (see e.g., Hannan and 
Freeman, 1977), strategic adaptation theories (see e.g., Sandberg and Hofer, 1982), motivational theories (see e.g., McClelland, 1961), and configuration theories (see e.g., Greiner, 1972), among others. According to Davidsson and Wiklund (2006), many of the above-mentioned perspectives focus on factors leading to survival and growth, while configuration studies are concerned with growth process. The key question addressed by configuration perspective is 'how growth should be managed?' The configuration perspective is often called the stages of growth perspective or the company life-cycle perspective; in this study, the term configuration perspective is used.

Miller and Friesen (1984) are among the first authors to use the term configuration in this sense, stating, "there is [a] somewhat "gestalt" or configural nature to the phases of the life-cycle. When we classify periods of organisational history according to their phase using a few key typing attributes, many other aspects of the organisation and its environment can be predicted - they reflect the themes delineated for each phase by the conceptual literature on the life-cycle.' Miller, Friesen, and Mintzberg (1984) and Hanks, Watson, Jansen, and Chandler (1993) claim that life cycle stages are best characterized as configurations. According to this view, the key typing attributes (for example, structures, systems, information procedures, etc.) tend to influence each other in such a manner that gives rise to a small number of configurations representing common developmental or transitional sequences.

The configuration perspective has been criticised as overly deterministic (see Churchill \& Lewis, 1983; Dodge, Fullerton, \& Robbins, 1994; Geroski, 2002; Miller, 1981; O’Farrell \& Hitchens, 1988; Perry, 1982; Siu \& Kirby, 1998; Stubbart \& Smalley, 1999; Whetten, 1987), conceptual (see Hanks \& Chandler, 1994) and overly general and simplistic (see Tornatzky et al., 1983; Whetten, 1987).

There exist numerous configuration models based on the recent extensive reviews (See Levie \& Lichtenstein 2010, Muhos et al. 2010, and Phelps et al. 2007). As configuration models are reviewed, three levels of analysis can be recommended: the identity of the studies, the description of the models, and the research methodology and assumptions (See. Muhos et al., 2010; Muhos, 2009). The reviews of the configuration perspective (Baird \& Meshoulam, 1988; d'Amboise \& Muldowney, 1988; Filley \& Aldag, 1980; Hanks, Watson, Jansen, \& Chandler, 1993; Hanks \& Chandler, 1994; Perry, 1982; Poutziouris, Binks, \& Bruce, 1999; Quinn \& Cameron, 1983; Scott \& Bruce, 1987; Lichtenstein 2010, Muhos et al. 2010, Phelps et al. 2007) have mostly focused on the first two levels. Less attention has been paid to the third level of analysis: research methodology (research strategies, choices, time horizons and empirical evidence) and basic assumptions of the models. In the academic discussion, the absence of this deeper level of analysis (See e.g. Burrell \& Morgan, 1979; Saunders, Lewis, \& Thornhill, 2007) often leads to confusion. For example, the configuration perspective is often described as overly deterministic, while many of the models are actually probabilistic.

The aim of this study is to fill the above-described gap by analysing 90 configuration studies conducted over the past 60 years. This study seeks to clarify the research methodologies of the configuration studies and explores one of the basic assumptions often presented in connection with the configuration studies: the deterministic nature of firm growth. The above-mentioned can be condensed into the following research questions:

RQ1. What kinds of research strategies, choices and time horizons, and empirical evidence are utilised for development of growth configuration models during the past six decades?

$R Q 2$. What kinds of parallel and alternative perspectives these models provide in relation to the assumption of deterministic firm growth?

This meta-analysis (see Glass, 1976) focuses on the configuration models of company growth and development. First in this study, 90 previously identified configuration 
studies and groups for analysis are presented. Second, by assessing selected attributes in the models, this study reviews methodological choices, research strategies, time horizons and use of empirical evidence in the configuration models. Third, this study explores one dimension of the research philosophy, the assumptions related to the nature of growth of the firm. The models are explored focusing on one of the most common critical viewpoints; the claim of overly deterministic nature of the models. By completing the above mentioned this study identifies well-covered areas, highlights trends and provides ideas for fresh research approaches. Based on this analysis, the common patterns and trends are described, and implications for further research are provided. This study is addressed to persons interested in the process perspective on company growth and development.

\section{Method}

This study is a meta-analysis. Meta-analysis focuses on analysis of a collection of research results in order to integrate some of the findings. Meta-analysis is needed when the literature of a certain type contains tens or even hundreds of studies dealing with the same area of interest (see Glass, 1976). This is the case with growth configuration studies.

The focus of this study is on configuration studies related to private companies. The population was limited to studies conducted in the past 60 years in order to provide comparable episodes, including sufficient number of units and to avoid problems of access to earlier-published studies. Preliminary analyses showed that models earlier than 1948 are relatively rare in the literature. The preliminary sample consisted of 120 configuration studies from the 1940s until today. The studies not primarily focusing on growth of private firm, such as those focused on growth of nations, mass movements, industries, clusters, networks, individuals in the organisation and models related to public, non-profit and volunteer organisations, were excluded from the analysis. The final sample includes 90 models.

The 90 reviewed models analysed in this study are presented in Appendix 1. Of the studies analysed, $69 \%$ are journal articles, $27 \%$ are books or book contributions and the rest are conference proceedings, research reports and available unpublished studies. The meta-analysis provided in this study is of both the entire sample and three groups of analysis: three 20-year periods starting from 1948. The analysis of the sample as a whole provides an overview of studies, and the separate analyses of three groups seek to detect commonalities and trends. The groups are presented in Appendix 1 and were made to provide a comparison and clarify the general trends in the configuration school of thought.

The meta-analysis is provided in this study both through the entire sample and through three groups of analysis. The analysis of the sample as a whole provides an overview of studies and the separate analyses of three groups seek to detect commonalities and trends. The groups are presented in Appendix 1. The trends in the configuration perspective were studied in three 20-year periods starting from 1948. The first group, early studies, consists of the studies published between years 1948 and 1968 . The second group, central studies, consists of the studies published between years 1969 and 1988. The third group, recent studies, consists of the studies published between years 1989 and 2008. In the first group 18 studies were found, in the second group 41 studies were found, and 31 studies were found in the third one. The groups were made to provide a comparison and clarify the general trends in the configuration school of thought. 


\section{Review of the methodology in configuration models}

\subsection{Research strategies, choices, and time horizons}

The research strategies and choices of the studies analysed are presented in the following table 1 .

[Table 1 should be placed here]

As the studies were analysed from the methodology perspective, it was shown that not all the studies clearly defined the research strategy used. Of the 90 studies, 56 defined the research strategy clearly, while 34 did not. Of the entire set of studies, 27 can be classified as case studies, 23 as surveys, 9 as action research, 4 as archival research, 4 as grounded theory, and 1 as experiment. No ethnographies were found. Both mono-method studies and multiple-methods studies were conducted. Of the 56 studies that define their research strategy, 47 were classified as mono-method studies and 9 as multi-method studies. In each group of analysis (early, central recent), the number of studies not describing the method is high in each category.

The case studies were the most common among the early and central studies and the second-most common among the recent studies. The most common type of case study across the sample was the descriptive, longitudinal-retrospective multiple case study. The early case studies all belong to this category. However, from central studies forward, variation increased. The speciality of the central case studies was single case studies and three longitudinal-observational studies. Moreover, exceptional examples of explorative and explanatory as well as cross-sectional case studies were provided. Among the recent case studies, explanatory studies and descriptive studies are more popular than exploratory ones. Cross-sectional data is provided.

There was only one survey among the early studies. More surveys were found among the central studies, but their popularity grew dramatically in the recent studies. Among the central surveys, both descriptive and explanatory approaches were found. Similarly, both longitudinal and cross-sectional data were shown. As the popularity of surveys grew among the recent studies, both descriptive and explanatory approaches are used equally, and some explorative research is also conducted. Both cross-sectional and longitudinal evidence are shown. Among the recent studies, there were more surveys to analyse: seven descriptive, seven explanatory, and three explorative studies were found. Both longitudinal and cross-sectional data were used.

The early, central and recent action research studies were all descriptive longitudinal studies. The action research was usually based on the author's extensive experience as a manager, management consultant and/or lecturer.

The most archival studies were found among the early studies and those included explorative and descriptive studies as well as longitudinal and cross-sectional studies. The only central archival study was explanatory-longitudinal. There were no archival research studies among the recent studies.

There were no grounded theory studies among the early studies. The only central grounded study was explanatory and longitudinal. The recent grounded studies were both explanatory and descriptive; all of them were longitudinal.

There were no studies described as experiments among the early and recent studies. There was only one experiment among the central studies, which was part of an explanatory and cross-sectional study with multiple methods. The case studies were the 
most common among the early and central studies and second common among the recent studies.

\subsection{Empirical evidence}

The growth configurations studies can be classified into taxonomies and typologies. For example, Miller (1996) divides configuration studies into groups of conceptual typologies and empirical taxonomies. Taxonomies are used for classifying empirical entities. Taxonomy begins empirically, with the goal of classifying cases according to their measured similarity or observed variables (see Bailey, 1994). The exception is the subsequent identification of empirical cases for conceptual typologies. Typologies are used for classifying conceptual entities (see Bailey, 1994). According to Bailey (1994), the typologies can be identified as qualitative classifications that are verbal and conceptual and lack empirical evidence. Bailey (1994) continues that even if empirical cases are identified for typologies, this can be accomplished without quantification. According to Miller (1996, p. 506) good typologies are more than anything products of inspired synthesis and a strong sense of conceptual aesthetics. However, Miller (1996) proposes three criteria for good typologies: First, they are well informed by theory and thus draw distinctions and relationships of conceptual importance. Second, their types invoke contrasts that facilitate empirical progress. Third, the elements or variables used to describe each type are shown to cohere in thematic and interesting ways.

The number of typologies and taxonomies in each episode are presented in Table 2:

[Table 2 should be placed here]

Among the early studies, there were more taxonomies than typologies throughout the group. However, the difference was not that great. Among the central studies, a majority of the studies were typologies. However, prior to year 1980, a vast majority of studies were typologies, and from 1980 onwards, a vast majority of the studies were taxonomies. Therefore, the 1970s can be characterised as a decade of typologies and the 1980s as a decade of taxonomies. This phenomenal rise of interest in taxonomies continued through the 1990s and the beginning of new millennium; in the group of recent studies, the vast majority of studies were taxonomies.

The main motivation of configuration theorists for providing conceptual typologies seems to be presenting a fresh and innovative viewpoint to the popular field. First, some of these studies proposed new conceptual approaches to stages of growth such as opensystem approach, key-crises approach, hurdles approach, evolutions and revolutions approach, organisational structure approach and entrepreneurial approach. Second, some of the studies provided new approaches or applications of formerly presented approaches to new contexts such as small business, industry, high-tech ventures, human service organisations and firm in network. Third, some of the studies provided a review and/or synthesis of the former concepts and based new approaches and theory building on these concepts. Finally, some studies provided adjustments of viewpoints or added details to former concepts.

The use of empirical evidence varies according to the selected research strategy and the time of publication. However, as the configuration perspective evolves through the three episodes of analysis, the case studies and surveys offer increasingly broad empirical evidence. As an example, the maximum number of cases provided is 6 among the early studies, 24 among the central studies and 645 among the recent ones. The same trend applies to the surveys. The maximum sample size is 50 among the early studies, 272 
among the central studies and 2903 among the recent studies. In the groups of action research, archival research, grounded theory and experiments, such trends are not visible.

As mentioned in the beginning of this study, the configuration perspective has been criticised of being conceptual. Based on this analysis, there has been both conceptual and empirical analysis among the configuration perspective. However, since the early eighties, majority of the configuration studies are based on empirical evidence and can be classified as taxonomies.

\section{Analysis of an assumption of deterministic growth}

The assumption that growth has a deterministic nature has been one of the most common sources of criticism on the configuration models. This has been noted both by many configuration scholars and by authors with external perspective to the configurations research (see Churchill \& Lewis, 1983; Dodge et al., 1994; Geroski, 2002; Miller, 1981; O’Farrell \& Hitchens, 1988; Perry, 1982; Siu \& Kirby, 1998; Stubbart \& Smalley, 1999; Whetten, 1987). According to Stubbart and Smalley (1999), empirical variations weaken the assertions of configuration models in several ways:

Stagnation occurs when subjects get 'stuck' at a particular stage. Regression occurs when subjects violate the logic of the model by moving backward through stages, instead of forward. Repetition occurs when subjects repeat particular stages instead of making transitions to the next stage. Skipping occurs when subjects bypass a stage. Erratic durations occur when subjects spend unusual lengths of time in particular stages. Erratic durations raise questions about the fixed-time element implicit in stage logic. Individual differences such as those listed above reveal the "Achilles heel" of stage models. Any variance undermines the assumption that the stages are rigidly programmed and predictable. (p. 282)

In this chapter, a closer look is taken into this critical viewpoint. The configuration models are revisited in order to clarify the model's relationship to determinism. Taking an in-depth view of one of the basic assumptions of the models may provide potential new paths for further development of the models.

As far as relationship to determinism is concerned, it is evident that not all of the models are purely deterministic. The models can be classified into two categories, probabilistic and deterministic, based on the assumed predictability of the development in terms of the type and sequence of the stages. According to Filley and Aldag (1980), the model is sequential when activity A must be developed to some point before activity B has a relative advantage. Therefore, if the company progresses through stages following the same order, the model is sequential. The non-sequential model does not assume that a company progresses through the stages in the same order. The deterministic models, according to Filley and Aldag (1980), assume predictable similarity in the types and sequences of the stages. In contrast, the probabilistic models assume similarity only in the types of stages (see Filley \& Aldag, 1980) with no deterministic sequence in between them. Figures 1 and 2 present illustrate this fundamental difference between deterministic and probabilistic models.

[Figure 1 should be placed here]

[Figure 2 should be placed here] 
Based on meta-analysis of the 90 configuration models, 68 studies were classified as deterministic and only 22 as probabilistic. The numbers of deterministic and probabilistic models across the groups of analysis are presented in Table 3:

[Table 3 should be placed here]

The typical deterministic models characterise the presented sequence of the stages as 'natural' (see Blake, Avis \& Jane, 1966); from that perspective, everything outside that order is against the natural order and leads to the risk of failure. As an extreme example, Schollhammer and Kurifoff (1979, p. 229) state that 'like living organisms, business organisations are subject to a life-cycle. They have period of youth, maturity, and decline...to be successful an organization must undergo and adapt to change.' From the deterministic perspective, management cannot control the emergence of predetermined stages and crises; it can only control the resolution (see for example Lippitt \& Schmidt, 1967). According to Steinmetz (1969); Cooper (1979); Tyebjee, Bruno, and McIntyre, (1983); Flamholtz (1995); Shim, Eastlick, and Lotz (2000); and Ndonzuau, Pirnay, and Surlemont (2002), to succeed companies must inescapably commit to living through and carefully planning for the predetermined stages of growth. Problems are expected to occur when managers do not think according to stages (Galbraith, 1982). According to Adizes (1979), models enable owner-managers to foresee the problems related to stages and to prescribe effective organisational treatments. Scott and Bruce (1987, p. 45) present their prescriptive model as 'a diagnostic tool in analysing the firm's present position and in planning what will be required as it progresses to the next stage of its development.' However, even the most deterministic studies agree that the models will not have the same level of certainty as 'models of planetary orbits' (Scott, 1971, p. 25). More often, the statements are less categorical, such as 'Our findings are predictive and give some indications of which priorities managers use across the three stages. However, we must be quick to point out that these data are descriptive, not normative' (Smith, Mitchell, \& Summer, 1985, p. 817). Further, Kazanjian (1988) and Kazanjian and Drazin (1989) find partial empirical support for predictability and sequence of stages among technologybased new ventures and claim that the performance fo firm depends on the match of organisational structure to the stage of growth (see Kazanjian \& Drazin, 1990).

The typical probabilistic models (see Buchele, 1967; Katz \& Kahn, 1966) assume that not every company goes through the same set of stages and/or crises in the same order or in the same form. Some of the early studies (see Buchele, 1967; Katz \& Kahn, 1966) and many later studies (see Mitra \& Pingali, 1999; Poutziouris, Binks, \& Bruce, 1999) state that companies may be born in any of the stages, avoid one or more stages, face a combination of stages and face them in different orders. The same has been noted among the central studies (see Filley \& Aldag, 1980; Kimberly, 1979; Parks, 1977a; Rhenman, 1973). As an example, Kimberly (1979, p. 7) states that 'there is no inevitable linear sequence of stages in organizational life, although there may be remarkable similarities among the developmental patterns of certain clusters of organizations. If there are laws that govern the development of organizations...they are yet to be discovered.' Further, among the recent studies, similar notions have been made (see for example Eggers, Leahy, \& Churchill, 1994; Garengo \& Bernardi, 2007; Hasenfeld \& Schmid, 1989). Hasenfeld and Schmid (1989, p. 245) state 'While there may be remarkable similarities in the developmental patterns of certain clusters of organizations, there is no inevitable linear sequence of stages in organizational development to parallel biological life cycles.' Eggers et al. (1994, p. 13) follow the same line of reasoning by pointing out common configurations and then stating that 'not all organisations follow the same developmental sequence.' 
There are metaphors used to describe company growth: organisational growth is seen analogous to a quantum leap (see Drucker, 1954), growth of a living organism (see Fayol, 1949), development of a behaviour system (Herbst, 1957), a floating object lifted by a wave (Filley, 1960), punctuated equilibrium (Filley, 1960; Lippitt \& Schmidt, 1967), a vehicle for success (Collins, Moore \& Unwalla, 1964), human capability development (Kroeger, 1974), amplification (McGuire, 1976), territorial occupation (Normann, 1977), hurdles (Parks, 1977a; Parks, 1977b), passages (Adizes, 1979), metamorphosis (Minzberg, 1979), creation (Kimberly, 1979), anthropomorphic evolution from infancy to adolescence (Filley \& Aldag, 1980) and cycle of creation and maintenance (Aplin \& Cosier, 1980).

Many (especially biological) metaphors used in the stages of growth theories lead to the illusion that all the models are deterministic. There are four distinctive biological analogies commonly utilised. Referring to some of the early configuration studies, Starbuck (1965) presents two distinctive categories of models focusing on patterns in the size and structure of an organisation: the cell-division models (see Haire, 1959) and metamorphosis models (see Fayol, 1949; Moore, 1959; Newman \& Logan, 1955; Whyte, 1948). Filley, House, and Kerr (1976) mention similar categories. More recent authors d'Amboise and Muldowney (1988) notice the cell division (Hosmer, Cooper, \& Vesper, 1977; McGuire, 1976) and metamorphosis (Churchill \& Lewis, 1983; Gervais, 1978; Greiner, 1972; Kroeger, 1974; Naoum, 1981; Parks, 1977a; Parks, 1977b; Robidoux \& Dell'Aniello, 1978; Thompson, 1976; Vargas, 1984) models as well. However, as the number of configurations studies increases, categories that are more distinctive can be found. Later on, Baird and Meshoulam (1988) and Stubbart and Smalley (1999) mention the same categories and add two distinctive categories, the life-cycle models (Adizes, 1979; Kimberly, 1979) and evolutionary models (see Blake et al., 1966). The basic types of configuration models are the cell division (changes in degree diversification through expansion of mass), the metamorphosis (transformations, discontinuous nature), the life cycle (stages, birth-growth-maturity-death, continuous) and the evolutionary (survival of the fittest, focus on environment) models

The meta-analysis presented in this section shows that a great majority of the studies offer deterministic viewpoint to the nature of the firm growth. However, probabilistic studies were found in all three groups of analysis, and their relative proportion among the central and the recent studies is growing. Among the recent studies, a third of the models are probabilistic in nature. However, the metaphors matter. In future studies, metaphors should be more carefully selected to avoid illusions of determinism when they are not intended.

\section{Discussion}

The aim of this study was to clarify the research methodology (research strategies, choices, time horizons and empirical evidence) of the growth configuration studies and to explore one of the basic assumptions often presented in connection with the configuration studies: the deterministic nature of firm growth. This was done through a meta-analytic review of growth configuration literature. The sample, presented in Appendix 1, was selected from the broad expanse of available configuration literature. By completing the above mentioned this study identified well-covered areas, highlighted trends and provided implications for future research. The key findings are condensed in the following answers to the research questions: RQ1. What kinds of research strategies, choices and time horizons, and empirical evidence are utilised for development of growth configuration models during the past six decades? RQ2. What kinds of parallel and 
alternative perspectives these models provide in relation to the assumption of deterministic firm growth?

The first research question was answered in section 3. At first glance, the results of this analysis seem twofold. On one hand, growth configuration research included examples of almost all commonly used research strategies, including case studies, surveys, action research, archival research, grounded theory and experiments. On the other, it was shown that nearly half of the early and central studies fail to describe the research strategies clearly. However, the trend is for the better: A great majority of the recent studies describe research methods successfully. The case studies, surveys were the most common strategies. While the case studies were most common among the early and central studies, the survey was the most common research strategy among the recent studies. A typical case study across the sample was a descriptive, longitudinalretrospective multiple case study while typical surveys across the sample were descriptive/explanatory longitudinal studies. As pointed out in the beginning of this study, the configuration perspective has been criticised as being overly conceptual. However, based on this analysis, there has been both conceptual and empirical analysis in the configuration perspective. From the early 1980s onward, the majority of studies have been based on empirical evidence and can be considered empirically based taxonomies.

The second research question is answered in section 4. Of the 90 models, 68 studies were classified as deterministic and only 22 as probabilistic based on the assumed predictability of development. The relative number of probabilistic models increased through the three episodes analysed and among the recent studies, a third of the models were probabilistic in nature. According to probabilistic models, there is no inevitable linear sequence of stages in organizational development to parallel biological life cycles. In a probabilistic perspective, a firm does not inevitably proceed through the same set of stages in linear order and therefore may be

- born in one or more of the stages (e.g. spin-offs),

- return from one stage to another (e.g. failure of the first business model),

- $\quad$ skip a stage (e.g. through acquisition),

- $\quad$ stay in one stage for a long time (e.g. stagnation) and

- go out of business unexpectedly (e.g. collapse of the business model).

The following Figure 3 illustrates some of the characteristics of probabilistic frameworks:

[Figure 3 should be placed here]

In the future, it is increasingly important to describe the methods clearly. By describing the research strategies, choices and time horizons clearly, it is possible to strengthen the methodological foundations of the field of growth configuration research. Methodologically and empirically sound studies should be provided in order to add concrete value to the growth configuration perspective. In future studies, the use of metaphors should be carefully considered to avoid unintended illusions of determinism. The metaphoric landscape may change in the future (see Phelps, Adams, \& Bessant, 2007). For example, Eggers et al. (1994) believe using the term stages of growth is inappropriate and potentially misleading as it refers to organismic stages. As examples of fresh perspectives based on probabilistic assumptions, Phelps et al. (2007) and later Levie and Lichtenstein (2010) proposes using the term 'states' instead of 'stages'. Drucker (1954) used the term already in the 1950s but it has not become established/customary among the configuration scholars. From this perspective, the company may proceed/return from one state to another through quantum leaps. Each state has a more or less stable set of challenges and opportunities. During each quantum leap (up or down skipping states), the set of challenges and opportunities may change. 
There are several limitations associated with this study. To some extent, this study is interpretative, and some subjectivity must be accepted. This study is meta-analytical in nature and in this sense does not contain any preliminary or secondary data. The data of this study consist of company-focused configuration studies conducted during the six previous decades and is limited to configuration studies published between 1948 and 2008. One challenge in the meta-analysis of the configuration viewpoint is that the original data is in many cases missing from the studies. There are configuration studies published earlier and later than the selected timespan, but these are not within the focus of this study. There are configuration studies that are not mentioned in this study, but a reasonable sample of the widely accepted configuration studies published during the last six decades are included in this analysis.

\section{Acknowledgements}

The author greatly appreciates the support of the University of California, Rady School of Management, La Jolla, CA, USA. Further, the author is grateful for the generous support by the Finnish Funding Agency for Innovation Tekes, the Council of Oulu Region, and the European Regional Development Fund. 


\section{References}

Abernathy, W. J. (1976). 'Production process, structure, and technological change'. Decision Sciences, Vol. 7, No. 4, pp. 607-619.

Abetti, P. A. (2001). 'Accelerated growth: Helping companies get and stay on the fast track'. International Journal of Manufacturing Technology and Management, Vol. 3, No. 1, pp. 1530 .

Adizes, I. (1979). Organizational passages: 'Diagnosing and treating lifecycle problems of organizations'. Organizational Dynamics, Vol. 8, No. 1, pp 3-25.

Adizes, I. (1989). Corporate lifecycles: How and why corporations grow and die and what to do about it, (1st ed.). Englewood Cliffs: Prentice Hall.

Aplin, J. C., \& Cosier, R. A. (1980). 'Managing creative and maintenance organization'. The Business Quarterly, Vol. 45, No. 1, pp. 56-64.

Bailey, K. D. (1994). Typologies and taxonomies: An introduction to classification techniques. London: Sage Publications.

Baird, L., \& Meshoulam, I. (1988). 'Managing two fits of strategic human resource management'. Academy of Management Review, Vol. 13, No. 1, pp. 116-128.

Beverland, M., \& Lockshin, L. S. (2001). 'Organizational life cycles in small New Zealand wineries'. Journal of Small Business Management, Vol. 39, No. 4, pp. 354-362.

Blake, R. R., Avis, W. E., \& Jane, S. (1966). Corporate Darwinism: An evolutionary perspective on organising work in the dynamic corporation (1st ed.). Houston: Gulf Publishing Company.

Buchele, R. B. (1967). Business policy in growing firms: A manual for evaluation (1st ed.). San Francisco: Chandler.

Burrell, G., \& Morgan, G. (1979). Sociological paradigms and organisational analysis (1st ed.). London: Heinemann Educational Books.

Cannon, J. T. (1968). Business strategy and policy (1st ed.). New York: Harcourt, Brace \& World.

Chandler, A. D. (1962). Strategy and structure: Chapters in the history of the American enterprise (1st ed.). Cambridge: Massachusetts Institute of Technology.

Christenson, R., \& Scott, B. (1964). Review of course activities (1st ed.). Lausanne: IMEDE.

Churchill, N. C., \& Lewis, V. L. (1983). 'The five stages of small business growth'. Harvard Business Review, Vol. 61, No. 3, pp. 30-50.

Collins, O. F., Moore, D. G., \& Unwalla, D. (1964). 'The enterprising man and the business executive'. MSU Business Topics, Vol. 12, No. 1, pp. 19-34.

Cooper, A. C. (1979). 'Strategic management: New ventures and small business'. In D. Schendel, \& C. W. Hofer (Eds.), Strategic management: A new view of business policy and planning (1st ed.). Boston: Little, Brown and Company.

d'Amboise, G., \& Muldowney, M. (1988). 'Management theory for small business: Attempts and requirements'. Academy of Management Review, Vol. 13, No. 2, pp. 226-240.

Davidsson, P., \& Wiklund, J. (2006). 'Conceptual and empirical challenges in the study of firm growth'. In P. Davidsson, F. Delmar \& J. Wiklund (Eds.), Entrepreneurship and the growth of firms (1st ed., pp. 39-61). Cheltenham: Edward Elgar Publishing.

Davis, R. C. (1951). The fundamentals of top management (1st ed.). New York: Harper \& Row.

Dodge, H. R., Fullerton, S., \& Robbins, J. E. (1994). 'Stage of the organizational life cycle and competition as mediators of problem perception for small businesses'. Strategic Management Journal, Vol. 15, No. 2, pp. 121-134.

Dodge, H. R., \& Robbins, J. E. (1992). 'An empirical investigation of the organizational life cycle model for small business development and survival'. Journal of Small Business Management, Vol. 30, No. 1, pp. 27-37. 
Drucker, P. F. (1954). The practise of management (1st ed.). New York: Harper and Brothers.

Eggers, J. H., Leahy, K. T., \& Churchill, N. C. (1994). 'Stages of small business growth revisited: Insights into growth path and leadership/management skills in low- and high-growth companies. Frontiers of Entrepreneurship Research 1994', Proceedings of the Fourteenth Annual Entrepreneurship Research Conference, Babson Park, pp. 131-144.

Fayol, H. (1949). General and industrial management (1st ed.). London: Pitman.

Filley, A. C. (1960). A theory of business growth (1st ed.). (Unpublished manuscript). University of Wisconsin, School of Commerce, Wisconsin.

Filley, A. C., \& Aldag, R. J. (1980). 'Organizational growth and types: Lessons from small institutions'. Research in Organizational Behavior, Vol. 2, pp. 279-321.

Filley, A. C., House, R. J., \& Kerr, S. (1976). Managerial process and organizational behavior (2nd ed.). Glenview: Scott Foresman.

Flamholtz, E. (1986). How to make the transition from an entrepreneurship to a professionally managed firm (1st ed.). San Francisco: Jossey-Bass.

Flamholtz, E. (1995). 'Managing organizational transitions: Implications for corporate and human resource management'. European Management Journal, 13(1), 39-51.

Galbraith, J. (1982). 'The stages of growth'. Journal of Business Strategy, Vol. 3, No. 1, pp. 70-79.

Garengo, P., \& Bernardi, G. (2007). 'Organizational capability in SMEs: Performance measurement as a key system in supporting company development'. International Journal of Productivity and Performance Management, Vol. 56, No. 5-6., pp. 518-532.

Garnsey, E. (1998). 'A theory of the early growth of the firm'. Industrial and Corporate Change, Vol. 7, No. 3, pp. 523-556.

Gartner, W. B., \& Brush, C. B. (1999). 'Entrepreneurship as organizing: Emergence, newness, and transformation'. Proceedings of 59th Annual Meeting of the Academy of Management, 7th August 1999. Chicago: Academy of Management.

Geroski, P. A. (2002). 'The growth of firms in theory and in practice'. In N. Foss, \& V. Mahnke (Eds.), Competence, governance, and entrepreneurship (2nd ed., pp. 168-186). Oxford: Oxford University Press.

Gervais, M. (1978). 'Toward organizational theory for small and medium-sized businesses'. Revue Française De Gestion, No. 15, pp. 37-49.

Glass, G. V. (1976). 'Primary, secondary, and meta-analysis of research'. Educational Researcher, Vol. 5, No. 10, pp. 3-8.

Greiner, L. (1972). 'Evolution and revolution as organizations grow'. Harvard Business Review, Vol. 50, No. 4, pp. 37-46.

Gudmundsson, S. V. (1998). 'New-entrant airlines' life-cycle analysis: Growth, decline and collapse'. Journal of Air Transport Management, Vol. 4, No. 4, pp. 217-228.

Haire, M. (1959). 'Biological models and empirical histories of the growth of organizations'. In M. Haire (Ed.), Modern organization theory (1st ed., pp. 272-306). New York: Wiley.

Hanks, S. H., \& Chandler, G. N. (1992). The growth of emerging firms: A theoretical framework and research agenda. The Proceedings of 7th Annual National Conference of the United States Association for Small Business and Entrepreneurship.

Hanks, S. H., \& Chandler, G. (1994). 'Patterns of functional specialization in emerging high tech firms'. Journal of Small Business Management, Vol. 32, No. 2. pp. 23-36.

Hanks, S. H., Watson, C. J., \& Jansen, E. (1991). 'Toward a configurational taxonomy of the organization life cycle'. In G. Hills, \& R. LaForge (Eds.), Research at the marketing/entrepreneurship interface, (1st ed.) . Chicago: University of Illinois Press.

Hanks, S. H., Watson, C. J., Jansen, E., \& Chandler, G. N. (1993). 'Tightening the life-cycle construct: A taxonomic study of growth stage configurations in high-technology organizations'. Entrepreneurship: Theory and Practice, Vol. 18, No. 2, pp 5-30.

Hasenfeld, Y., \& Schmid, H. (1989). 'The life cycle of human service organizations: An administrative perspective'. Administration in Social Work, Vo. 13, No. 3/4, pp. 243-269. 
Herbst, P. G. (1957). 'Measurement of behaviour structures by means of input-output data'. Human Relations, Vol. 10, pp. 335-346.

Hite, J. M., \& Hesterly, W. S. (2001). 'Research notes and commentaries: The evolution of firm networks: From emergence to early growth of the firm'. Strategic Management Journal, Vol. 22, No. 3, pp. 275-286.

Hosmer, L., Cooper, A., \& Vesper, K. (1977). The entrepreneurial function: Text and cases on smaller firms (1st ed.). Englewood Cliffs: Prentice-Hall.

Jawahar, I. M., \& McLaughlin, G. L. (2001). 'Toward a descriptive stakeholder theory: An organizational life cycle approach'. Academy of Management Review, Vol. 26, No. 3, pp. 397414.

Katz, D., \& Kahn, R. L. (1966). The social psychology of organizations (1st ed.). New York: Wiley.

Kaulio, M. A. (2003). 'Initial conditions or process of development? Critical incidents in the early stages of new ventures'. $R \& D$ Management, Vol. 33, No. 2, pp. 165-175.

Kazanjian, R. K. (1988). 'Relation of dominant problems to stages of growth in technology-based new ventures'. Academy of Management Journal, Vol. 31, No. 2, pp. 257-279.

Kazanjian, R. K., \& Drazin, R. (1989). 'An empirical test of a stage of growth progression model'. Management Science, Vol. 35, No. 12, pp. 1489-1503.

Kazanjian, R. K., \& Drazin, R. (1990). 'A stage-contingent model of design and growth for technology based new ventures'. Journal of Business Venturing, Vol. 5, No. 3, pp. 137-150.

Kimberly, J. (1979). 'Issues in the creation of organizations: Initiation, innovation, and institutionalization'. Academy of Management Journal, Vol. 22, No. 3, pp. 437-457.

Kroeger, C. V. (1974). 'Managerial development in the small firm'. California Management Review, Vol. 17, No. 1, pp. 41-46.

Kuratko, D. F., \& Hodgetts, R. M. (2001). Entrepreneurship: A contemporary approach (5th ed.). Fort Worth: Harcourt.

Lavoie, D., \& Culbert, S. A. (1978). 'Stages of organization and development'. Human Relations, Vol. 31, No. 5, pp. 417.

Levie, J. D. and Lichtenstein, B. B. (2010) 'A terminal assessment of stages theory: introducing a dynamic states approach to entrepreneurship'. Entrepreneurship Theory and Practice, Vol. 34, No. 2, pp. 317-350.

Lippitt, G. L., \& Schmidt, W. H. (1967). 'Crises in a developing organization'. Harvard Business Review, Vol. 45, No. 6, pp. 102-112.

McCann, J. E. (1991). 'Patterns of growth, competitive technology, and financial strategies in young ventures'. Journal of Business Venturing, Vol. 6, No. 3, pp. 189-208.

McGuire, J. W. (1976). 'The small enterprise in economics and organization theory'. Journal of Contemporary Business, Vol. 5, No. 2, pp. 115-138.

Miller, D. (1981). 'Toward a new contingency approach: The search for organizational gestalts'. Journal of Management Studies, Vol. 18, No. 1, pp. 1-26.

Miller, D. (1996). 'Configurations revisited'. Strategic Management Journal, Vol. 17, No. 7, pp. 505-512.

Miller, D., \& Friesen, P. H. (1984). 'A longitudinal study of the corporate life cycle'. Management Science, Vol. 30, No. 10, pp. 1161-1183.

Miller, D., Friesen, P. H., \& Mintzberg, H. (1984). Organizations: A quantum view (1st ed.). Englewood Cliffs: Prentice Hall

Minzberg, H. (1979). The structure of organisations (1st ed.). Englewood Cliffs: Prentice Hall

Mintzberg, H. (1973). 'Strategy-making in three modes'. California Management Review, Vol. 16, No. 2, pp. 44-53.

Mintzberg, H. (1984). 'Power and organization life cycles'. Academy of Management Review, Vol. 9, No. 2, pp. 207-224. 
Mitra, R., \& Pingali, V. (1999). 'Analysis of growth stages in small firms: A case study of automobile ancillaries in India'. Journal of Small Business Management, Vol. 37, No. 3, pp. 62-63.

Moore, D. G. (1959). 'Managerial strategies'. In W. Warner, \& N. Martin (Eds.), Industrial man (1st ed., pp. 219-226). New York: Harper.

Muhos, M. S., S . (2009). 'Configuration models of business growth and development: A preliminary analytical framework'. Proceedings of Nordic Innovation Research Conference (NIR 2008), 8-9 Dec., 2008 (1st ed., pp. 1-21). Oulu: University of Oulu.

Muhos, M., Kess, P., Phusavat, K., \& Sanpanich, S. (2010). 'Business growth models: Review of past 60 years'. International Journal of Management and Enterprise Development, Vol. 8, No 3, pp. 296-315.

Naoum, N. (1981). 'Knowing small and medium-sized businesses well'. Revue Commerce, Vol. 82, No. 1 , pp. 54-56.

Ndonzuau, F. N., Pirnay, F., \& Surlemont, B. (2002). 'A stage model of academic spin-off creation'. Technovation, Vol. 22, No. 5, pp. 281-289.

Newman, W. H., \& Logan, J. P. (1955). Management of expanding enterprises: Report of round table discussions by leading business and professional men (1st ed.). New York: Columbia University Press.

Normann, R. (1977). Management for growth (1st ed.). New York: Wiley.

O'Farrell, P. N., \& Hitchens, D. (1988). 'Alternative theories of small-firm growth: A critical review'. Environment and Planning, Vol. 20, No. 3, pp. 1365-1383.

Olson, P. D. (1987). 'Entrepreneurship and management'. Journal of Small Business Management, Vol. 25, No. 3, pp. 7-13.

Parks, G. M. (1977a). 'How to climb a growth curve: Eleven hurdles for the entrepreneur-manager. Part I'. Journal of Small Business Management, Vol. 15, No. 1, pp. 25-29.

Parks, G. M. (1977b). 'How to climb a growth curve: Eleven hurdles for the entrepreneur-manager. Part II'. Journal of Small Business Management, Vol. 15, No. 2, pp. 41-45.

Perry, C. (1982). 'Stage theories of small business growth'. Management Forum, Vol. 8, No. 4, pp. 190-203.

Phelps, R., Adams, R., \& Bessant, J. (2007). 'Life cycles of growing organizations: A review with implications for knowledge and learning'. International Journal of Management Reviews, Vol. 9, No. 1, pp. 1-30.

Poutziouris, P., Binks, M., \& Bruce, A. (1999). 'A problem-based phenomenological growth model for small manufacturing firms'. Journal of Small Business and Enterprise Development, Vol. 6, No. 2, pp. 139-152.

Quinn, R. E., \& Cameron, K. (1983). 'Organizational life cycles and shifting criteria of effectiveness: Some preliminary evidence'. Management Science, Vol. 29, No. 1, pp. 33-51.

Rhenman, E. (1973). Organization theory for long-range planning (1st ed.). New York: Wiley.

Robidoux, J., \& Dell'Aniello, P. (1978). Les crises administratives dans les PME en croissance (1st ed.). Québec: G. Morin.

Rutherford, M. W., Buller, P. F., \& McMullen, P. R. (2003). 'Human resource management problems over the life cycle of small to medium-sized firms'. Human Resource Management, Vol. 42, No. 4, pp. 321-335.

Saunders, M., Lewis, P., \& Thornhill, A. (2007). Research methods for business students. London: Financial Times/Prentice Hall.

Scanlan, B. K. (1980). 'Maintaining organizational effectiveness-A prescription for good health'. Personnel Journal, Vol. 59, No. 5, pp. 381-386.

Schollhammer, H., \& Kurifoff, A. H. (1979). Entrepreneurship and small business management (1st ed.). New York: John Wiley \& Sons.

Scott, B. R. (1971). Stages of corporate development - Part 1, Case no. 9-371-294. Boston: Harvard Business School, Intercollegiate Case Clearing House. 
Scott, M., \& Bruce, R. (1987). 'Five stages of growth in small business'. Long Range Planning, Vol. 20, No. 3, pp. 45-52.

Shim, S., Eastlick, M. A., \& Lotz, S. (2000). 'Examination of US Hispanic-owned, small retail and service businesses: An organizational life cycle approach'. Journal of Retailing and Consumer Services, Vol. 7, No. 1, pp. 19-32.

Siu, W., \& Kirby, D. A. (1998). 'Approaches to small firm marketing. European Journal of Marketing', Vol. 32, No. 1/2, pp. 40-60.

Smith, K. G., Mitchell, T. R., \& Summer, C. E. (1985). 'Top level management priorities in different stages of the organizational life cycle'. Academy of Management Journal, Vol. 28, No. 4, pp. 799-820.

Stam, E. (2007). 'Why butterflies don't leave: Locational behavior of entrepreneurial firms'. Economic Geography, Vol. 83, No. 1, pp. 27-50.

Stanworth, M., \& Curran, J. (1976). 'Growth and the small firm: An alternative view'. Journal of Management Studies, Vol. 13, No. 2, pp. 95-110.

Starbuck, W. H. (1965). 'Organizational growth and development'. In J. March (Ed.), Handbook of organisations (1st ed., pp. 451-534). Chicago: Rand McNally \& Co.

Starbuck, W. H. (1966). 'The efficiency of British and American retail employees'. Administrative Science Quarterly, Vol. 11, No. 3, pp. 345-385.

Steinmetz, L. L. (1969). 'Critical stages of small business growth: When they occur and how to survive them'. Business Horizons, Vol. 12, No. 1, pp. 29-34.

Stubbart, C. I., \& Smalley, R. D. (1999). 'The deceptive allure of stage models of strategic processes'. Journal of Management Inquiry, Vol. 8, No. 3, pp. 273-286.

Swiercz, P. M., \& Lydon, S. R. (2002). 'Entrepreneurial leadership in high-tech firms: A field study'. Leadership \& Organization Development Journal, Vol. 23, No. 7, pp. 380-389.

Terpstra, D. E., \& Olson, P. D. (1993). 'Entrepreneurial start-up and growth: A classification of problems'. Entrepreneurship: Theory and Practice, Vol. 17, No. 3, pp. 5-20.

Thompson, J. D. (1976). 'How to run a successful business'. Canadian Business, Vol. 49, No. 7, pp. 56-58.

Torbert, W. R. (1974). 'Pre-bureaucratic and post-bureaucratic stages of organization development'. Interpersonal Development, Vol. 5., No. 1, pp. 1-25.

Tornatzky, L. G., Eveland, J. D., Boylan, M. G., Hetzner, W. A., Johnson, E. C., Roitman, D., Schneider, J. (1983). The process of technological innovation: Reviewing the literature (1st ed.). Washington: National Science Foundation.

Tyebjee, T. T., Bruno, A. V., \& McIntyre, S. H. (1983). Growing ventures can anticipate marketing stages (1st ed.). Cambridge: Marketing Science Institute.

Van de Ven, A. H., Hudson, R., \& Schroeder, D. M. (1984). 'Designing new business startups: Entrepreneurial, organizational, and ecological considerations'. Journal of Management, Vol. 10, No. 1, pp. 87-108.

Vargas, G. (1984). 'Les crises de croissance de la PMI-PME [Growth crisis in small industries and small firms]'. Revue Française De Gestion, Vol. Janvier-Février, No. 44, pp. 13-22.

Whetten, D. A. (1987). 'Organizational growth and decline processes'. Annual Review of Sociology, Vol. 13, No. 1, pp. 335-358.

Whyte, W. F. (1948). Human relations in the restaurant industry (1st ed.). New York: McGrawHill.

Zadek, S. (2004). 'The path to corporate responsibility'. Harvard Business Review, Vol. 82, No. 12, pp. $125-32,150$ 


\section{Appendix 1: The sample}

\begin{tabular}{|c|c|c|}
\hline $\begin{array}{l}\text { The early studies } \\
(1948-1968)\end{array}$ & $\begin{array}{l}\text { The central studies } \\
(1969-1988)\end{array}$ & $\begin{array}{l}\text { The recent studies } \\
(1989-2008)\end{array}$ \\
\hline $\begin{array}{l}\text { 1. Whyte, } 1948 \\
\text { 2. Fayol, } 1949 \\
\text { 3. Davis, } 1951 \\
\text { 4. Drucker, } 1954 \\
\text { 5. Newman \& Logan, } 1955 \\
\text {. Herbst, } 1957 \\
\text { 7. Moore, } 1959 \\
\text { 8. Haire, } 1959 \\
\text { 9. Filley, } 1960 \\
\text { 10. Chandler, } 1962 \\
\text { 11. Christenson \& Scott, } 1964 \\
\text { 12. Collins et al., } 1964 \\
\text { 13. Blake et al., } 1966 \\
\text { 14. Katz \& Kahn, } 1966 \\
\text { 15. Starbuck, } 1966 \\
\text { 16. Buchele, } 1967 \\
\text { 17. Lippitt \& Schmidt, } 1967 \\
\text { 18. Cannon, } 1968\end{array}$ & 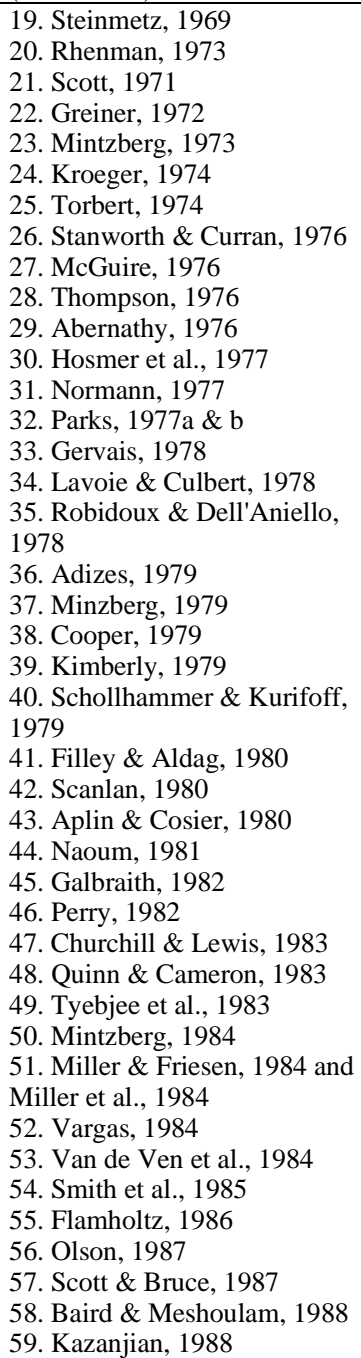 & $\begin{array}{l}\text { 60. Hasenfeld \& Schmid, } 1989 \\
\text { 61. Kazanjian \& Drazin, } 1989 \\
\text { 62. Adizes, 1989 } \\
\text { 63. Kazanjian \& Drazin, } 1990 \\
\text { 64. McCann, 1991 } \\
\text { 65. Hanks et al., 1991 } \\
\text { 66. Dodge \& Robbins, } 1992 \\
\text { 67. Hanks \& Chandler, } 1992 \text { and } \\
\text { Hanks et al., 1993 } \\
\text { 68. Terpstra \& Olson, } 1993 \\
\text { 69. Hanks \& Chandler, } 1994 \\
\text { 70. Dodge et al., 1994 } \\
\text { 71. Eggers et al., 1994 } \\
\text { 72. Flamholtz, 1995 } \\
\text { 73. Garnsey, 1998 } \\
\text { 74. Gudmundsson, } 1998 \\
\text { 75. Poutziouris et al., } 1999 \\
\text { 76. Gartner \& Brush, } 1999 \\
\text { 77. Mitra \& Pingali, } 1999 \\
\text { 78. Shim et al., 2000 } \\
\text { 79. Abetti, 2001 } \\
\text { 80. Beverland \& Lockshin, } 2001 \\
\text { 81. Jawahar \& McLaughlin, } 2001 \\
\text { 82. Hite \& Hesterly, } 2001 \\
\text { 83. Kuratko \& Hodgetts, } 2001 \\
\text { 84. Ndonzuau et al., } 2002 \\
\text { 85. Swiercz \& Lydon, } 2002 \\
\text { 86. Kaulio, 2003 } \\
\text { 87. Rutherford et al., } 2003 \\
\text { 88. Zadek, 2004 } \\
\text { 89. Garengo \& Bernardi, } 2007 \\
\text { 90. Stam, 2007 }\end{array}$ \\
\hline
\end{tabular}




\section{Tables and figures:}

Table 1 The research strategies and research choices

\begin{tabular}{lcccc}
\hline Research strategies & Early strategies & Central strategies & Recent strategies & Total \\
\hline Defined & 10 & 22 & 24 & 56 \\
Not defined & 8 & 19 & 7 & 34 \\
\hline Case study & $5^{*}$ & 15 & 7 & \\
Survey & 1 & 5 & 17 & \\
Action research & 3 & 4 & 2 & \\
Archival research & 3 & 1 & - & \\
Grounded theory & - & 1 & 3 & \\
Experiment & - & 1 & - & Total \\
Ethnography & - & - & - & 97 \\
\hline Research choices & Early studies & Central studies & Recent studies & \\
\hline Mono-method & 9 & 17 & 21 & 34 \\
Multiple methods & 1 & 5 & 3 & 90 \\
Not defined & 8 & 19 & 7 & 31 \\
\hline Number of studies & 18 & 41 &
\end{tabular}

* The studies using multiple methods are included in more than one category of research strategies. For example, one study using survey and archival research strategies is presented in both survey and archival research categories in the table.

Table 2 The number of typologies and taxonomies

\begin{tabular}{lcccc}
\hline Type & Early studies & Central studies & Recent studies & Total \\
\hline Typologies & 7 & 24 & 7 & 38 \\
Taxonomies & 11 & 17 & 24 & 52 \\
\hline Number of studies & 18 & 41 & 31 & 90 \\
\hline
\end{tabular}

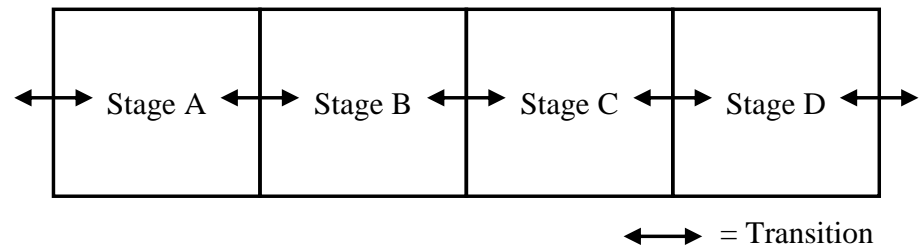

Figure 1 Characteristics of deterministic stage model 


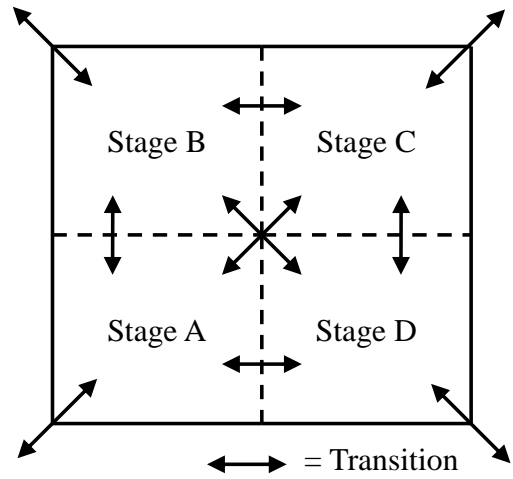

Figure 2 Characteristics of probabilistic stage model

Table 3 The number of typologies and taxonomies

\begin{tabular}{lllll}
\hline & Early studies & Central studies & Recent studies & Total \\
\hline Deterministic & 15 & 32 & 21 & 68 \\
Probabilistic & 3 & 9 & 10 & 22 \\
\hline Number of studies & 18 & 41 & 31 & 90 \\
\hline
\end{tabular}

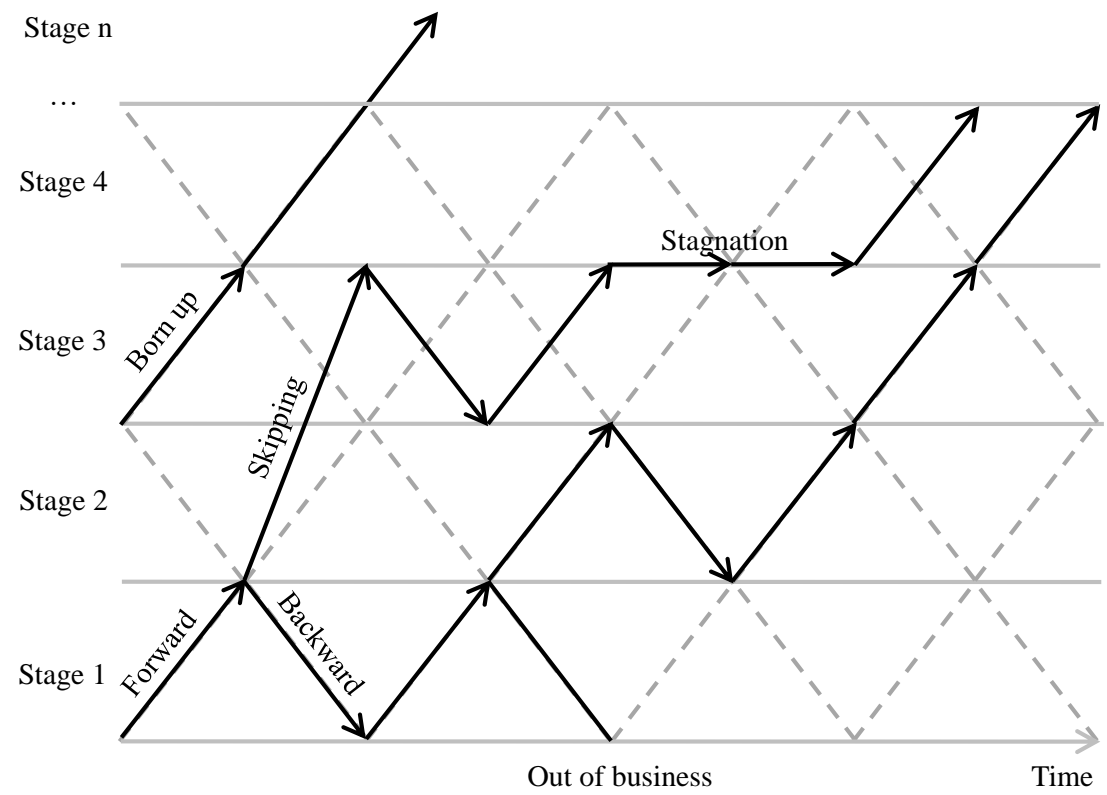

Figure 3 Illustration of some characteristics of the probabilistic configurations framework 